\title{
OBSTACLES AND POSSIBILITIES FOR PARTICIPATION IN SPORT AFTER SPINAL CORD INJURY
}

Kęstutis Skučas

Lithuanian Sports University, Kaunas, Lithuania

\begin{abstract}
Research background and hypothesis. Studies have shown that persons after spinal cord injury rarely continue participating in sport (Stryker, Burke, 2000; Hanson, Nabavi, 2001; Stephan, Brewer, 2007). This could be caused by the obstacles that the persons face due to the motor disorder after spinal cord injury (Wu, Williams, 2001; Tasiemski et al., 2004). Hypothesis: persons with spinal cord injury while being involved in disabled sport face the same problems irrespectively of gender.

Research aim was to determine the obstacles and possibilities for involvement and participation in sport after spinal cord injury.

Research methods. The questionnaire method was used to collect sport participation data (Tasiemski et al., 2004) and determine socialization agents of persons after spinal cord injury (Williams, 1994). The athletic identity assessment scale (Brewer, Cornelius, 2002) was used in the research.

Research results. Data showed that the majority of the subjects after spinal cord injury were not involved in sport; $11.9 \%$ did sports 1 hour per week, $13.2 \%-2-3$ hours per week, $10.6 \%$ - more than 6 hours per week. The value of athletic identity of paraplegic subjects was equal to 23 points, and that of tetraplegic subjects -18 points (statistically significant data difference between the two groups when $\mathrm{p}<0.05$ ). It was found that athletic identity value of men after spinal cord injury (22 points) was statistically significantly higher compared to that of women (16 points, $\mathrm{p}<0.05$ ). Lack of adapted sport facilities $-49.6 \%$, equipment $-53.2 \%$, coaches $-48.4 \%$ and financial resources $-42.0 \%$ proved to be the major obstacles to participate in sport for persons after spinal cord injury.

Discussion and conclusions. According to the research, only a minority of persons after spinal cord injury identified themselves as athletes. It was found that the main social agents involving disabled persons into the mainstream of sport were other disabled persons, rehabilitation and physical therapists, coaches and other sports professionals. Persons after spinal cord injury believed that the main reasons of non-participation in sport was lack of information about disabled sport, also lack of sports equipment, financial problems and lack of sports professionals. Most persons after spinal cord injury participated or would participate in sport with the aim of getting fit, strengthening the upper body part, socializing, feeling the joy of life. The majority of results of the study were similar to the results of other researchers (Tasiemski et al., 2004) who analyzed disabled persons' problems while involving in sport.
\end{abstract}

Keywords: involvement in disabled sport, athletic identity, social agents.

\section{INTRODUCTION}

$\mathrm{P}$ roblems of disabled sport have recently been discussed in detail in both scientific and popular literature. The interest has been caused by the active integration of disabled sport into international organizations all over the world. Disabled sport began as a kind of rehabilitation, but nowadays it is acquiring a new meaning and perspectives, which allows it to be perceived in a wider sense - as the right of every citizen, an integral part of the democratic and humanization processes. The 2012 Paralympic Games could be the most outstanding illustration of the phenomenon. The London Paralympics revealed a few new and important aspects of disabled sport 
development: disabled sport is becoming more and more professional (the competition among athletes has been increasing), it is becoming more popular all over the world (there appear new sports branches accessible to disabled persons, disabled people get involved in sport more actively), it is becoming an important event not only for disabled persons, but also for the global society (the London Paralympics were the first in Paralympic Games history to sell out), the attitude towards disabled athletes is changing (government representatives do not spare nice epithets for disabled athletes, like "the most gifted part of the humanity", "superpeople", etc.). Disabled sport has advanced not only in quantitative, but also in qualitative terms. The constant improvement in the result of Paralympic athletes shows that in most countries disabled sports are well-organized to enable disabled athletes to develop their sports skills. However, the object of scientific research is not only professional disabled sport. New research fields also aim at the problems of participation in disabled sport, as the high performance of disabled athletes depends on the number of participants (Miller, 2009). Studies show that even in countries with high-performing athletes the number of disabled athletes is quite low. Besides, disabled sport in the broad sense promotes social integration and socialization of disabled people, improving their psychosocial health and physical condition (Sherrill, Williams, 1996; Sherrill, 1998; Tasiemski et al., 2000; Skučas, 2010). Participating in sport is an attractive form of self-expression, communication and realization of expectations and aspirations for disabled persons (Hanson, Nabavi, 2001; Tasiemski et al., 2004; Kehn, Kroll, 2009). For these reasons, research on sports participation of disabled persons is highly relevant today.

It has been officially admitted that disabled sport is facing a crisis in Lithuania today. The situation is closely related both to the fact that the number of disabled athletes participating in the Paralympic Games has been decreasing (the Lithuanian participant number in the Beijing 2008 Paralympic Games was 26, while in the London 2012 Paralympic Games - only 11) and the results achieved by disabled athletes. The sparkle of medals won in the Paralympic Games dimmed disabled sport problems until now. For the first time in the mass media Lithuanian Paralympic Committee and Disabled Sports Federation leaders spoke about serious problems faced when organizing disabled sport. Their statements show that Lithuania lacks research on disabled sport issues, which would help improve the situation and develop disabled sport. Questions whether sport is accessible for physically disabled, what encourages disabled persons to participate in sport, possibilities and obstacles to get involved and participate in sport have been little researched, though the issues are very important. Moreover, it is important to look into another problem which has not been discussed in Lithuania yet - the disabled persons' attitude towards sport, whether they find sport attractive, the athletic identity of disabled persons involved in sport, the way they perceive and feel about themselves in the role of an athlete.

Modern athletic identity issues are highly relevant - whether it depends on the severity of disability, history of sport involvement and qualification of athletes (Nasco, Webb, 2006). The article analyzes problems and possibilities for involvement and participation in sport of persons with severe and very severe disability after spinal cord injury.

Spinal cord injury affects motor, sensory and vegetative functions (Sherrill, 1998). After spinal cord injury persons suffer sensory and motor disorders which complicate movement and are the main disability factors (Tasiemski et al., 2000; Skucas, 2010). Studies have shown that persons after spinal cord injury rarely continue participating in sport (Stryker, Burke, 2000; Hanson, Nabavi, 2001; Stephan, Brewer, 2007). This could be caused by the obstacles that the persons face due to the motor disorder after spinal cord injury: such persons have little access to equipment necessary for the involvement in sport (e. g. special sports wheelchairs), poor access to sports facilities which are poorly or not adapted for persons with physical disabilities; acquiring new sports skills necessary for the involvement in disabled sport is also problematic ( $\mathrm{Wu}$, Williams, 2001; Tasiemski et al., 2004).

The aim of the research was to determine the obstacles and possibilities for involvement and participation in sport after spinal cord injury.

\section{RESEARCH METHODS}

The questionnaire by T. Tasiemski and others (2004) was employed in the research. It contains questions on demographic data of the subjects (age, gender, injury details, education, occupation) 
and their participation in sport before and after the injury. The questionnaire on disabled sport socialization by T. Williams (1994) was used to determine sport socialization agents and factors. It submitted questions on sport socialization agents and various organizations providing useful information and encouraging involvement in disabled sport after spinal cord injury.

The athletic identity assessment scale (Brewer, Cornelius, 2002) was used in the research. The scale is a seven-item questionnaire assessing the person's feelings of self-attribution to the athlete's role. The athletic identity grading scale is divided into three sub-categories: social identity (the depth of the athlete's perception of the role), differentiation (the athlete's perception of the role compared with other roles, such as a friend's role, a family member's role, etc.), and negative effects (negative emotional response rates due to inability to practice and participate in sports competitions). The answers to the questions scored from one (answer "strongly disagree") to seven ("strongly agree"). The scores of individual subscales were summed, and the total score of each individual athletic identity score was derived.

During the period of 2011-2012 the research included 106 disabled persons from all over Lithuania (74 men and 32 women), of which 29 men and 14 women participated in sports activity. Athletic identity of the persons only involved in sports was determined. The participants were selected into the research using the improbability objective method of group formation. The group included persons after spinal cord injury. The age of the subjects ranged from 18 to 45 years, the time after spinal cord injury was from 2 to 15 years. The type of disability of the respondents was spinal cord injury. According to the severity of disability two groups of respondents were formed: a very severe disability group - persons with tetraplegia (wheelchair users, paralyzed legs and partially paralyzed hands; 28 subjects), and a severe disability group - persons with paraplegia (wheelchair users, paralyzed legs; 78 subjects).

The research results were processed applying the software program SPSS 12.0. The arithmetic mean (x) and the standard deviations (S) were calculated. Data statistical differences between men and women after spinal cord injury and between tetraplegic and paraplegic subjects were assessed using Student's (t) test. Data were considered statistically significant at the significance level of $\mathrm{p}<0.05$.

\section{RESEARCH RESULTS}

The questionnaire data showed that the majority of the subjects after spinal cord injury were not involved in sport; $11.9 \%$ did sports 1 hour per week, $13.2 \%-2-3$ hours per week, $10.6 \%$ - more than 6 hours per week. Men were more actively involved in sport than women. Persons with severe disabilities were less often involved in sport.

Only a small number of the respondents identified themselves as athletes. Only $10.6 \%$ of athletic identity scores equaled to 28 points. The research revealed that athletic identity depended on the severity of disability - the more severe the disability, the less number of disabled persons after spinal cord injury identifying themselves as athletes. The value of athletic identity of paraplegic subjects was equal to 23 points, and that of tetraplegic subjects -18 points (statistically significant data difference between the two groups when $p<0.05)$. It was found that athletic identity value of men after spinal cord injury (22 points) was statistically significantly higher compared to that of women (16 points, $\mathrm{p}<0.05)$. Athletic identity of both men and women depended on the number of hours doing sport per week: the more hours a week the respondents spent doing sport, the higher their athletic identity was. Athletic identity of men depended on sports qualification - athletic identity was highest among athletes with international qualification (29 points). Women's athletic identity was not affected by sports qualification.

The research results revealed that sport socialization agents, which were the first to provide the respondents with the necessary information about disability sport and to encourage participation in sport, were other disabled persons, rehabilitation and physical therapists, coaches and other sports professionals (Table 1). The most useful information about disability sport was provided at rehabilitation centers, at events organized by public organizations; very little information was obtained from the mass media.

Lack of adapted sport facilities, equipment, coaches and financial resources proved to be the major obstacles to participate in sport for persons after spinal cord injury (Table 2).

The research shows that majority of persons after spinal cord injury participated in sport with the aim of getting fit, strengthening the upper body part, socializing, feeling the joy of life. In addition to these reasons, women did sport to regulate weight, and men - to increase self-esteem and to participate in sports competitions (Table 3). 


\begin{tabular}{|l|c|c|c|}
\hline \multicolumn{1}{|c|}{ Socialization agents and context } & All subjects, $\%$ & Men, $\%$ & Women, $\%$ \\
\hline Doctors & 0.7 & 0.8 & 0.6 \\
\hline Educators & 0.9 & 0.9 & 0.8 \\
\hline Rehabilitation specialists, physical therapists & 2.8 & 2.9 & 2.8 \\
\hline Other disabled persons & 3.5 & $3.7^{*}$ & 3.3 \\
\hline Coaches, sport instructors & 3.4 & $3.6^{*}$ & 3.1 \\
\hline Rehabilitation centers & 3.0 & 3.1 & 3.1 \\
\hline Mass media & 1.2 & 1.2 & 1.1 \\
\hline Public disabled organizations & 3.7 & 3.6 & 3.7 \\
\hline
\end{tabular}

Table 1. Socialization environment and agents that provided necessary information about disabled sport

Note. $*-p<0.05$, statistically significant difference between men and women after spinal cord injury.

\begin{tabular}{|l|c|c|c|}
\hline \multicolumn{1}{|c|}{$\begin{array}{c}\text { Reasons for non-involvement in sport of } \\
\text { disabled persons }\end{array}$} & All subjects, \% & Men, \% & Women, \% \\
\hline Lack of adapted sports facilities & 49.6 & 48.8 & 49.6 \\
\hline Lack of sports equipment & 53.2 & 53.8 & 52.8 \\
\hline Little choice of disabled sports branches & 25.3 & 24.3 & 26.9 \\
\hline $\begin{array}{l}\text { Limited independence due to lack of daily } \\
\text { living skills }\end{array}$ & 30.6 & 29.5 & 33.1 \\
\hline Absence of access to favorite sport & 25.8 & 23.6 & 27.2 \\
\hline Lack of time due to work or other reasons & 28.2 & 29.4 & 23.5 \\
\hline Financial problems & 42.0 & 43.3 & 42.7 \\
\hline Transport problems & 37.4 & 38.6 & 36.3 \\
\hline Lack of coaches and sports specialists & 48.4 & 49.2 & 47.8 \\
\hline Others (including pain and family obligations) & 18.9 & 19.8 & 22.5 \\
\hline
\end{tabular}

Table 2. Reasons for noninvolvement in sport of persons after spinal cord injury

\begin{tabular}{|l|c|c|c|}
\hline $\begin{array}{c}\text { Reasons for involvement in sport of disabled } \\
\text { persons }\end{array}$ & All subjects, \% & Men, \% & Women, \% \\
\hline Getting fit & 74.5 & 71.3 & 74.2 \\
\hline Strengthening the upper body part & 59.6 & 58.8 & 67.6 \\
\hline Socializing & 58.4 & 59.7 & 52.9 \\
\hline Feeling joy & 54.3 & 53.5 & 38.2 \\
\hline Increasing self-esteem & 46.6 & 47.1 & 40.2 \\
\hline Weight watching & 42.3 & 38.4 & 58.7 \\
\hline Competitions & 43.4 & 44.8 & 30.1 \\
\hline Travelling & 26.8 & 27.3 & 17.9 \\
\hline Others & 6.1 & 5.4 & 10.5 \\
\hline
\end{tabular}

Table 3. Reasons for involvement in sport of persons after spinal cord injury

\section{DISCUSSION}

Comparison of the research data with the data of similar research works on athletic identity values reveals the fact that Lithuanian athletic identity is lower than that of disabled swimmers (Martin et al., 2005) and able-bodied athletes (Brewer, Cornelius, 2002) from Great Britain. Similar results were obtained comparing athletic identity data in the aspects of gender and hours spent doing sport per week. The results show that athletic identity of persons after spinal cord injury in comparison to that of able-bodied persons is highly affected by injury, social limitations caused by the disability and the absence of status of the disabled athlete.

Comparison of the results with British (Tasiemski et al., 2004) research results shows that in Great Britain sport socialization agents in the order of importance are other disabled persons, coaches or other sports professionals, while in Lithuania they are other disabled persons or physical therapists. Thus, it can be concluded that both in Lithuania and Great Britain disabled sport socialization is influenced by similar agents, 
but the opinion about the relevance of specialists differs. Information sources on disabled sport are also different. In Great Britain the necessary information is provided not only at rehabilitation centers, disabled and able-bodied sports organizations and other organizations, but also in the mass media.

Comparison of the situations in Lithuania and Great Britain (Tasiemski et al., 2004) results in the fact that Lithuanian disabled athletes have fewer possibilities for doing sport. The major obstacle to involvement in sport in Great Britain appears to be lack of daily living skills, while in Lithuania it appears to be lack of information, equipment and professionals. It can be concluded that in Great Britain (Tasiemski et al., 2004) disabled athletes do not face financial problems (lack of money, equipment, transport), while in Lithuania disabled athletes alongside with lack of special equipment, information and professionals also encounter financial, transport and other problems. This shows that in Lithuania disabled persons encounter more obstacles to sport involvement due to the economic situation.

Though other research works on reasons for involvement in sport of persons after spinal cord injury show similar results (Tasiemski et al., 2000, 2004), this research confirms that there are no significant differences in the obtained results in aspect of gender.

\section{CONCLUSIONS AND PERSPECTIVES}

1. The majority of persons after spinal cord injury are not involved in sport at all, only a very small percentage of women and men with severe disability are involved in sport.

2. Only a small number of persons after spinal cord injury identify themselves as athletes. Athletic identity depends on the severity of disability the more severe the disability, the less number of disabled persons after spinal cord injury identifying themselves as athletes.

3. The main social agents, involving disabled persons into sport, are other disabled persons, rehabilitation specialists, physical therapists, coaches and other sports professionals.

4. Disabled persons are encouraged to participate in sport at rehabilitation centers and sports clubs, the mass media has a minor influence on the process.

5. Persons after spinal cord injury believe that the main obstacles for non-participation in sport are lack of information about disabled sport, lack of sports equipment, lack of financial resources and sports professionals.

6. Most persons after spinal cord injury participate in sport with the aim of getting fit, strengthening the upper body part, socializing, feeling the joy of life. Also women do sport to regulate weight, and men - to increase self-esteem and to participate in the competitions.

\section{REFERENCES}

Brewer, B. W., Cornelius, A. E. (2002). Norms and factorial invariance of the Athletic Identity Measurement Scale, Academic Athletic Journal, 15, 103-113.

Hanson, C., Nabavi, D. (2001). The effects of sports on level of community integration as reported by persons with spinal cord injury. American Journal of Occupational Therapy, 55 (33), 332-338.

Kehn, M., Kroll, T. (2009). Staying physically active after spinal cord injury: A qualitative exploration of barriers and facilitators to exercise participation. Public Health, 9, 168-172.

Martin, J. J., Adams-Mushett, C., Smith, K. L. (2005). Athletic identity and sport orientation of adolescent swimmers with disabilities. Adapted Physical Activity Quarterly, 12, 113-123.

Miller, K. E. (2009). Sport-related identities and the toxic jock. Journal of Sport Behaviour, 32, 69-91.
Nasco, S. A., Webb, W. M. (2006). Towards an expanded measure of athletic identity: The inclusion of public and private dimensions. Journal of Sport and Exercise Psychology, 28, 434-453.

Sherrill, C. (1998). Adapted Physical Activity, Recreation and Sport: Cross-disciplinary and Lifespan (5 ed.). Boston, MA: WCB Mc Crawl-Hill.

Sherrill, C., Williams, T. (1996). Disability and Sport: Psychosocial perspectives on Inclusion. Integration and Participation. Sport Science Review, 5, 42-64.

Skučas, K. (2010). Sportuojančiu ir nesportuojančiu fiziškai neigalių asmenų socializacijos galimybės psichosocialinès sveikatos aspektu. Filosofija. Sociologija, 21 (2), 179-185.

Stephan, Y., Brewer, B. W. (2007). Perceived determinants of identification with the athlete role among 
elite competitors. Journal of Applied Sport Psychology, 19, 67-79.

Stryker, S., Burke, P. J. (2000). The past, present, and future of an identity theory. Social Psychology Quarterly, 63, 284-297.

Tasiemski, T., Bergstrom, E., Savic, G., Gardner, B. P. (2000). Sports, recreation and employment following spinal cord injury - A pilot study. Spinal Cord, 38, 173-184.

Tasiemski, T., Kennedy, P., Gardner, B. P., Blaikley, R. A. (2004). Athletic identity and sport participation in people with spinal cord injury. Adapted Physical Activity Quarterly, 21, 364-378.

Williams, T. (1994). Sociological perspectives on sport and disability: Structural-functionalism. Physical Education Review, 17 (1), 14-24.

Wu, S. K., Williams, T. (2001). Factors influencing sport participation among athletes with spinal cord injury. Medicine and Science in Sports and Exercise, 33 (2), 177-181.

\title{
ASMENŲ, PATYRUSIŲ NUGAROS SMEGENŲ PAŽEIDIMĄ, DALYVAVIMO SPORTINĖJE VEIKLOJE KLIŪTYS IR GALIMYBĖS
}

\author{
Kęstutis Skučas \\ Lietuvos sporto universitetas, Kaunas, Lietuva
}

\section{SANTRAUKA}

Tyrimo pagrindimas ir hipoteze. Tyrimais nustatyta, kad asmenys, patyrę nugaros smegenų pažeidimą, retai tęsia sportinę veiklą (Stryker, Burke, 2000; Hanson, Nabavi, 2001; Stephan, Brewer, 2007). Taip atsitinka dažniausiai dèl judejjimo funkcijos sutrikimo (Wu, Williams, 2001; Tasiemski ir kt., 2004). Hipotezè: asmenys, patyrę nugaros smegenų pažeidima, issitraukdami į sportinę veiklą susiduria su panašiomis problemomis nepriklausomai nuo lyties.

Tikslas - nustatyti asmenų, patyrusių nugaros smegenų pažeidimą, dalyvavimo ir ịsitraukimo į sportinę veiklą kliūtis ir galimybes.

Metodai. Anketavimo metodu surinkti dalyvavimo sportinejje veikloje duomenys (Tasiemski ir kt., 2004) ir nustatyti asmenu̧, patyrusių nugaros smegenų pažeidimą, sporto socializacijos agentai (Williams, 1994). Tyrimo metu naudota Sportininko identiteto vertinimo skalè (Brewer, Cornelius, 2002).

Rezultatai. Apklausos duomenys rodo, kad dauguma tirtuju, patyrusių nugaros smegenų pažeidimą, nesportuoja. $11,9 \%$ sportuoja vieną valandą per savaitę, $13,2 \%-2-3$ valandas per savaitę, sportui daugiau nei 6 valandas per savaitę skiria 10,6\% tiriamujų. Paraplegikų sportininko identiteto reikšmé siekẻ 23 balus, tetraplegiku - 18 balu (gautas statistiškai patikimas skirtumas tarp šiu grupių duomenu $-\mathrm{p}<0,05$ ). Buvo nustatyta, kad vyrų (22 balai), patyrusių nugaros smegenų pažeidimą, sportininko identiteto reikšmè buvo statistiškai patikimai didesnè, lyginant su moterų ( 16 balų, $\mathrm{p}<0,05)$. Didžiausios kliūtys, trukdančios patyrusiesiems nugaros smegenų pažeidimą sportuoti, buvo neigaliesiems pritaikytų sporto bazių $(49,6 \%)$, inventoriaus $(53,2 \%)$, trenerių $(48,4 \%)$ ir lèšų $(42,0 \%)$ trūkumas.

Aptarimas ir išvados. Save suvokia kaip sportinininkus tik nedaugelis asmenų, patyrusių nugaros smegenu pažeidimą. Pagrindiniai socialiniai agentai, itraukę neigaliuosius i sportinę veiklą, buvo kitas neigalus asmuo, reabilitologai ir kineziterapeutai, treneriai, kiti sporto specialistai. Asmenys, patyrę nugaros smegenų pažeidima, mano, kad pagrindinès nedalyvavimo sportinejje veikloje kliūtys yra žinių apie neigaliujų sportą stoka, sportinio inventoriaus, lěšų ir sporto specialistų trūkumas. Dauguma asmenų patyrusių nugaros smegenų pažeidimą, sportuoja arba sportuotų norèdami igyti gerą fizinę formą, stiprinti viršutinę kūno dali, išvykti iš namų ir pabendrauti su žmonėmis, pajusti džiaugsmo pojūtị. Dauguma šio tyrimo rezultų buvo panašūs, lyginant su kitų tyrẻjų nagrinejjusių neigaliujų isitraukimo ị sportinę veiklą problemas, rezultatais (Tasiemski ir kt., 2004).

Raktažodžiai: ịtraukimas i i neigaliujų sporta, sportininko identitetas, socialiniai agentai.

Gauta 2013 m. vasario $7 \mathrm{~d}$.

Received on February 7, 2013 